\title{
Using Graphic Organizers to Improve Students' Reading Comprehension at Grade XI of SMAN 3 Lubuk Basung
}

\author{
Gustina $^{1, *}$ Hermawati Syarif ${ }^{1}$
}

\author{
${ }^{1}$ Universitas Negeri Padang \\ *Corresponding author. Email: gustina.anas@gmail.com
}

\begin{abstract}
The background of this research is the students who their achievement is still under the minimum standard (KKM) of learning success and most of them are unwilling to pay serious attention to the text they are reading. This research aims to solve students' problem in learning process especially reading comprehension using graphic organizer. The method used is classroom action research (CAR). The data were collected trough reading test, observation, field note and interview. The result showed that students' reading comprehension is improved by using graphic organizer technique. The average of their reading test in pre-test is $61,67,71.25$ is in cycle one and 78.75 is in cycle two. Furthermore, graphic organizer also gives significant effect such as students are more active and confidence in teaching and learning process and they could comprehend text well.
\end{abstract}

Keywords: Graphic Organizer, Reading Comprehension

\section{INTRODUCTION}

Reading is one of language skills that helps the students are able to understand written text and material. Reading is a process that is used by readers to get information based on what they read. In reading process, the reader does not only have to understand the meaning word by word, but he also needs to comprehend the whole meaning of the text. Furthermore, the reader will get knowledge, information, ideas, and sequence of events and details of the text. Developing the students' reading and comprehension skills early in their education means that preparing them for the "real world", because in the next era, in their life, they will find many things in English form such as book, newspaper, magazine, job vacancy advertisement, letter, and others. Reading also helps students to obtain more information so that they can learn many other subjects. Many articles and journals found on the internet are in English.

Furthermore, reading comprehension requires an interaction between the text and the reader's knowledge. Reading comprehension is the ability of the students to interpret and comprehend what the writer expresses in reading texts. According to Irwin [1] reading comprehension is a process where the reader comprehend what the writer means in the text. It means that the reader can relate the ideas in the sentences and between the sentences. The reader also relates the ideas between one paragraph and another paragraph. In addition, Smith [2] defines comprehension as the capacity for understanding between thoughts and ideas, applying what the readers have read and understood. So, the readers should interpret what they have read about the text.
Additionally, the students are motivated to improve their ability in reading comprehension. However, many students have low comprehension in reading activities during the learning process. It is proved by the fact that only $16 \%$ of 25 students reached KKM when they got first semester midterm test in reading test. In the other word, their achievement is still under the minimum standard of learning success. It is also indicated by the students' attitude toward reading or their interest in reading. Most of them are unwilling to pay serious attention to the text they are reading. They just look at the point they think they know or at the picture if it is available on the text. They do not show their curiosity to comprehend the text. As a result, they are not able to capture the ideas that the writer means. Of course these situations make them fail to comprehend the texts. They get difficulty to catch the writer's messages. The effect is that they cannot answer the provided question because they cannot find the answer in the text. This situation made the students and teacher worry especially because they should take the final examination later.

In order to improve students' ability in reading comprehension, the researcher implies graphic organizer technique. According to Bouchard [3] graphic organizer provides a visual representation of how the text is organized and is an efficient and useful tool when teaching text structure. Then, Hibbard and Wagner in Purwaningsih [4] state graphic organizer is a diagram that represents a relationship directed by a thinking-skill verb. In line with Hibbard, Gregory and Carolyn in Cahyono [5] state graphic organizers are useful thinking tools that allow students to organize information and allow students to see their thinking. It means, by using Graphic Organizer the 
students organized the text in visual diagram based on the text concept.

Then Ciascai [6] defines graphic organizers as representations, pictures or models used for processing textual information. They facilitate understanding of knowledge when there is a large amount of information to work with, in a given limited time. In short, graphic organizer is a diagram that represents a relationship that allows students to organize information and represents the relationships between facts, terms, and or ideas within a learning task.

Graphic organizer helps the students understand the text easily. Based on Burke [7] graphic organizer helps students to recognize and to analyze the features of different textbook in order to approach the text more strategically. Then, according to Ciascai [6], there are many functions of graphic organizers in reading comprehension, they assist learners to: first, clarify and organize information into categories (main idea, supporting details, topic sentence, facts, opinion, etc). Second, organize information in a paragraph for better understanding. Third construct meaning of difficult words and sentence dividing into lexis. Fourth, understand the context by associating with prior knowledge. And fifth, identify conceptual and perceptual errors that may occur in the course of reading a passage. In conclusion, graphic organizer has function to help students to organize and recognize the information, analyze the features of the text, and find the meaning based on the text.Based on illustration above, the researcher uses graphic organizer technique in order to help students to improve their reading comprehension.

\section{METHOD}

The design of this research is classroom action research which it aims is to find out practical problem solving. Furthermore, classroom action research is an action research done by the teacher in the classroom which is helped by collaborator to overcome problems or to improve education practice and to develop the researchers' teaching quality. In this research, the researcher will collaborate with other teachers become a team who works together to overcome the problems which are faced by teacher and others during the teaching process.

The participants of this research are researcher, collaborator, and students. The researcher teach grade XI at SMA N 3 Lubuk Basung. Then, collaborator is an English teacher in the same school. He helped the researcher to conduct the research. The students are grade XI MIPA 1 that there are 24 students all of them. The researcher chose the participants of this grade because the researcher herself teach English subject in this class.

Related to the data that will be collected, there are two kinds of instruments will be used, quantitative and qualitative data. The instruments for quantitative data are as follows:

\section{Task}

The reading task is done at the end of each meeting. The task is in the form of reading comprehension of hortatory exposition text. The reading task is used to find out the students' ability in reading in implementing graphic organizer to improve their reading comprehension. 2. Test

Test is used to collect the data about the students' ability in comprehending reading texts. The students are given some texts followed by the questions based on the curriculum and teaching materials of grade XI. To get the validity of test, the researcher applied content validity which refers to constructing the comprehension based on indicators proposed in the syllabus of curriculum 2013.

\section{Observation sheet}

Observation sheet is one of the instruments used by the researcher to get the data or information about student and teacher's activities and factors that influence teaching and learning process during conducting the research accurately. The observation is used to support the data collection become valid. The observation is done when the teaching and learning process is happening in the classroom.

\section{Field Note}

The researcher also write field note about what she find during teaching and learning process. It is hope that weaknesses find in previous meeting can make some improvement for the next meeting and make the result of teaching and learning process better. So, the researcher can reach the goal.

\section{Interview}

The interview will be used to collect data or information that could not be obtained by using the observation sheet or field note. The researcher will interview the students to know students' responses, opinions, or impression in learning reading through graphic organizer.

\section{RESULTS AND DISCUSSION}

The findings of this research relate to research questions that guided the study. Data were analyzed to find out to what extent can Graphic organizer strategy improve students' reading comprehension and the factors that influence the changes of students' reading comprehension by using Graphic organizer strategy at grade XI of SMA N 3 Lubuk Basung. These data were obtained from reading comprehension test, take note and observation checklist, and interview.

There are 10 questions of reading test were answered by the students for each in cycle 1 and cycle 2 . Then, it was analyzed by using statistic. The result of reading test shows the improvement of students' reading comprehension by using Graphic Organizer. In addition, observation checklist, field note and interview were used in order to know factors of improvement of students' reading comprehension. The observation checklist and field note were filled by contributor and interviews were obtained from students' information of teaching process by implementing graphic organizer.

Furthermore, the improvement of students' reading comprehension can be seen from students' score in pretest, cycle one and cycle two. Their scores in reading comprehension improve for every cycle. The average of 
their scores in reading comprehension can be seen in the following graph.

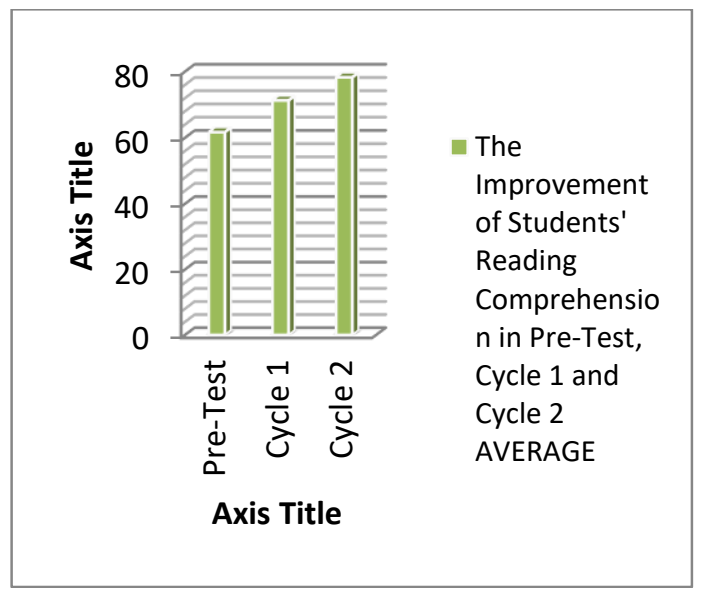

Fig. 1 The Improvement of Students' Reading Comprehension

Figure above shows that progress of reading comprehension got from pre-test, cycle one and cycle two. The average of reading comprehension test in pre-test is 61.67. Then, the average in cycle 1 is 71.25 . The last in cycle 2 is 78.75 . These show improvement of students' reading comprehension by using Graphic Organizer technique.

1) Pre-Test

Before doing research, the researcher gave pre-test for the students in order to know their ability in reading comprehension. The pre-test aimed is to identify students' problem in reading comprehension and their problem in classroom situation. After analyzing students' scores in reading test, the average of pre test is 61.67 , it means that students reading comprehension is low.

To overcome students' reading comprehension problem, it was applied graphic organizer technique which conducted in two cycles.

2) The Result of Cycle One

There are four meting in cycle one. Every meeting consisted of one reading topic. In other words, there were three reading topics discussed for first cycle.Before giving test to the students, the researcher and collaborators do some activities in cycle one, they are planning, action, observation and reflection.

Planning is an activity that should be done in classroom action research where researcher discuss with the collaborator to make some planning after that the researcher prepare everything related to the research such as design the lesson plan which included the activities in applying graphic organizer, prepare several topics of the texts, prepare media/pictures related to the topic, set the rules that the students should know to make the teaching and learning process ran well, prepare the instruments such as observation sheet, field notes, interview guidance and students' attendance list and arrange the research schedule.

After planning, researcher started teaching in action stage. In this part, researcher applied graphic organizer technique. Here, researcher start teaching by greeting them, check students' attendance, encourage students' previous knowledge by asking questions and explain material. Then, the students are asked to read selected reading text and filled in the chart in the group. After that, the teacher invited them randomly to contribute to the master chart and showed a finding meaning graphic organizer such gave a brief example of the chart use, and explain chart purpose. The last teacher gave task to check their comprehension of the text that they have read. These same activities are done for several meeting in cycle one.

While researcher was teaching students, collaborators observed and created field note of learning process. Based on collaborators observation in cycle one, when teacher greet students, they respond to the students' greeting.

Meanwhile, the teacher use material that helps students to develop confidence. This material is about analytical exposition. However, there are many students have no confident to respond the material; just active students have confidence to respond it. The factor of this situation because they did not took attention to the teacher' explanation and there are some vocabularies that they did not know. Although, students seems not took attention, teacher always try to explain it clearly, and give more material about real situation such as regular study that they can understand.

After observation and giving task to the students, teacher gave test for them in order to know their comprehension in cycle one. Then, teacher and collaborator reflected teaching process in the last meeting. In this step the researcher and collaborator analyzed the data collected by analyzing the students' based on score and the students' reading comprehension test. The researcher analyzed reviews and responds to be previous learning process in the first cycle to create the next plan for the next cycle. It means that the researcher and the collaborator evaluate the problems that has not been solved, and they checked whether the instruments which were used optimally or not.

The researcher also notice the results of each meeting by interpreting the graphics she is used on the tests and find out what factors influenced the problems. At this step, the 
researcher strived to find out whether Graphic Organizer strategy can improve students' reading comprehension and to find the factors influence.

In this cycle one, some students show their improvement in reading comprehension. But, some of them are not. It can be seen from their score after reading test.

Table.1 Frequencies of students score in cycle one

\begin{tabular}{|l|l|l|}
\hline No & Score & Frequency \\
\hline 1 & 50 & 5 \\
\hline 2 & 60 & 3 \\
\hline 3 & 70 & 5 \\
\hline 4 & 80 & 6 \\
\hline 5 & 90 & 5 \\
\hline
\end{tabular}

Based on the table above, it can be seen that students who get score above 70 are 16 students, and students who get under 70 are 8 students. Furthermore, after analyzing the data, the averages of students' reading test in cycle one is 71.25. This average has improvement from pretest. Although there is an improvement of students reading comprehension, researcher found some problem in this stage. First, there were only several students who active in discussion groups, and some students were not. Second, the students paid attention and tried to understand to the chart purpose, but many students still confused. Third, there were some students try to asked to the person next to them when they were doing task. Then, the students have limited vocabulary about text.

Here, there is an interview script about teaching process in cycle one.

$\mathrm{T}$

: Menurut pendapatmu, apakah teks nya sukar dipahami? (In your opinion, is the material difficult to understand?

S : Saya kurang memahami pada beberapa bagian teks (I don't understand in part of text.

$\mathrm{S} \quad$ : Tidak terlalu sukar dipahami (It is not too difficult)

S : Sedikit sukar karena kurangnya kosakata bahasa inggris (It's a bit difficult, because I don't know the meaning of words.)

From this interview, the there are students who thought that text is difficult. However there are students showed that it was not difficult for them. In order to be satisfied with the strategy given, the researcher need to continue into cycle 2.
3) The Result of Cycle Two

Based on the reflection in the previous cycle, there might befocusing problems that should be solved, students' comprehension and teacher's teaching strategies or teacher's monitoring in teaching process. Therefore, it was necessary to set up the plans for the coming cycle.

The following plans teacher's activities were set up as follows:

a. Teacher and collaborator paid more attention to the students who do not give respond, less motivated and reluctant to study.

b. Teacher gave material that is more interested to the students

c. The teacher provided more feedback to the students ${ }^{\text {ee }}$ reading activities.

d. Teacher provide class discussion for students

The activities in this cycle are same with previous cycle. There are fivemeetings with four kinds of reading topics of hortatory exposition. To activate the students ${ }^{\text {ee }}$ background knowledge, the teacher asked the students several questions dealing with the topic.The differences in this cycle were on the emphasis of the problems on students reading comprehension, group members, and monitoring.

During the explanation and discussion, the teacher also gave more attention to the passive students. They were provided more monitoring from the teacher rather than the active ones. If they made mistakes, they were corrected indirectly, particularly for less confident students. It was done to avoid hurting them and making them down.

After doing the test, the result indicated the average of the students score in this cycle is 81.25. In otherwords, there was significant increasing average of the students score in this cycle comparing with the previous cycle. Then, the following table shows the frequency of students' score in cycle two.

Table.2 Frequencies of students score in cycle two

\begin{tabular}{|l|l|l|}
\hline No & Score & Frequency \\
\hline 1 & 60 & 2 \\
\hline 2 & 70 & 7 \\
\hline 3 & 80 & 9 \\
\hline 4 & 90 & 4 \\
\hline 5 & 100 & 2 \\
\hline
\end{tabular}

From the table 2, it can be seen students' reading comprehension had improvement than previous cycle. Students who got score above KKM (70) are 22 students and students who got 
score under 70 are 2 students. This shows improvement of students reading comprehension.

Concluding from the first cycle and the second cycle, there were improvements of students reading comprehension test result. In cycle 1 , the average of students score is 71,25 and after doing cycle 2 , it is 78.75 . It means using graphic organizer can improve students reading comprehension.

Furthermore, based on the observation and field note, showed that many students gave respond in teaching and learning process. Many of them are active by asking and answering questions in discussions and do the task and test by themselves without asking to person next to them.

Based on illustration above, it can be stated that graphic organizer can improve students' reading comprehension. Graphic organizer is a technique which can be applied in teaching reading. According to Bouchard [3] graphic organizer provides a visual representation of how the text is organized and is an efficient and useful tool when teaching text structure. Then, Hibbard and Wagner in Purwaningsih [4] state graphic organizer is a diagram that represents a relationship directed by a thinking-skill verb. In line with Hibbard, Gregory and Carolyn in Cahyono [5] state graphic organizers are useful thinking tools that allow students to organize information and allow students to see their thinking. It means, by using Graphic Organizer the students organized the text in visual diagram based on the text concept.

Furthermore, Majeed [8] has conducted a research entitled "The Effect of Using Graphic Organizers on Writing (A Case Study of Preparatory College Students at Umm-Al-Qura University)" he found that the mean score for writing was increased in all five traits after the graphic organizers intervention; however, the maximum increase was observed in organization reaching $(75.5 \%)$ instead of( $48 \%)$ and word choice reaching $(75 \%)$ instead of $(48.5 \%)$. The overall mean score for writing after the participants had received their graphic organizers' training did increase significantly to approach $(68.88 \%)$. It was only $(45 \%)$ before intervention. The difference in mean between the writing of students before and after they received the graphic organizers' training was almost (24\%). The results of this study proved that the graphic organizers model had significantly improved the students' writing ability and had positively impacted their attitudes towards this skill.

Purwaningsih [4] has conducted a research entitled "Improving Students' Reading Comprehension through Graphic Organizers at SMP N 15 Yogyakarta in The Academic Year of 2012/2013", The finding of this study is that the using of Graphic Organizers could improve the students' reading comprehension at SMP N 15 Yogyakarta, then the quantitative data shown, the mean scores increased from 59.71 in the pre test to 67.29 in the first post test, to 72.00 in the second post test. In addition, researcher found improvement of students' reading comprehension by applying using graphic organizer in two cycles. The students can be more active in teaching learning process, and be more confident to respond teachers' explanation. Then, they can comprehend text especially hortatory exposition text.

\section{CONLUSIONS}

Based on the findings, it can be concluded:

1. Students' score in reading test were improve from pre-test, cycle one and cycle two. The average in pretest is 61.7 , cycle one is 71.25 and cycle two is 78.75. It means that students' reading comprehension has improvement.

2. Graphic organizer is a technique that can improve students' reading comprehension.

3. Graphic organizer has benefit for students such they could be more active and confidence in teaching and learning process, want to give respond to the teacher's explanation, and comprehend the text well.

\section{ACKNOWLEDGMENTS}

First and foremost, the researcher would like to say Alhamdulillah all praises to Allah SWT for giving me strength and encouragement during all the moments in completing this research. Then, the researcher gives a massive thank to Mrs. Hermawati Syarif as the advisor. The researcher greatly appreciates all her enormous contributions of time and ideas, as well as her support of the researcher's interest in the current topic of the research. It was an honour to have such a knowledgeable advisor who challenged and encouraged to do the best throughout the whole time spent on writing the research. Without her guidance and persistent help, it would not have been possible. The researcher would also like to show the gratitude to Mrs. Yeni Rozimela, Mrs. Desvalini Anwar, as well as many other amazing university lecturers. The researcher has greatly benefited from their lectures, which will always remember as the best time of life.

\section{REFERENCES}

[1] Irwin, Teaching reading comprehension processes, 2nd ed. Upper Saddle River, NJ: Pearson, 1990.

[2] B. D. Smith, Breaking through: College reading. Pearson, 2013.

[3] M. Bouchard, Comprehension strategies for English language learners: 30 Research-based reading strategies that help students read, understand, and really learn content from their textbooks and other nonfiction materials. Teaching Strategies, 2005.

[4] S. Purwaningsih, 'Improving Students' Reading Comprehension through Graphic Organizers at SMP N 15 Yogyakarta in the Academic Year of 2012/ 2013," UNY, Yogyakarta, 2013. 
[5] B. Y. Cahyono, "Techniques and Strategies to Enhance English Language Learning," State University of Malang, Malang, 2011.

[6] L. Ciascai, "Using Graphic Organizers in Intercultural Education," Acta Didactica Napocensia, vol. 2, no. 1, pp. 9-18, 2009.

[7] J. Burke, "Tools For Reading, Thinking and Writing may reproduce for classroom use only,” English Companion, 2013. [Online]. Available: www.englishcompanion.com.

[8] A. M. Tayib, "The Effect of Using Graphic Organizers on Writing: A Case Study of Preparatory College Students at Umm-Al-Qura University," International Journal of English Language and Linguistic Research, vol. 3, no. 1 , pp. 15-36, 2015. 